\title{
SISTEM INFORMASI PENGELOLAAN DATA PENDUDUK KANTOR KELURAHAN KARANG BARU KOTA MATARAM BERBASIS WEBSITE
}

\author{
Nurul Nadiyatun Sholihah ${ }^{[1]}$, Ariyan Zubaidi ${ }^{[1]}$, Isaskar Diri ${ }^{[2]}$ \\ ${ }^{[1]}$ Dept Informatics Engineering, Mataram University \\ Jl. Majapahit 62, Mataram, Lombok NTB, INDONESIA \\ ${ }^{[2]}$ Social and Community Empowerment Section, Kantor Lurah Karang Baru \\ Jl. Dr. Soetomo No.31, Karang Baru, Kec. Selaparang, Kota Mataram \\ Email:nurulnadiya19@gmail.com, zubaidi13@unram.ac.id
}

\begin{abstract}
Abstrak
Perkembangan teknologi informasi disertai dengan teknologi komputer yang canggih dalam waktu yang relatif singkat telah memberikan pengaruh yang begitu besar terhadap berbagai aspek kehidupan manusia di setiap lapisan masyarakat. Perkembangan teknologi yang sangat cepat mengharuskan instansi mengikuti perkembangan tersebut, oleh karena itu suatu instansi membutuhkan sistem informasi yang dapat mendukung kebutuhannya dalam mencapai efisiensi dan efektifitas kerja demi meningkatkan pelayanan kepada masyarakat. Dengan suatu sistem informasi data kependudukan maka diharapkan pengolahan data akan menjadi lebih mudah. Kantor Kelurahan Karang Baru di Kecamatan Selaparang, Kota Mataram, Provinsi Nusa Tenggara Barat ini masih menggunakan pengelolaan data secara manual dengan menggunakan Microsoft Word dan Microsoft Excel sehingga diharapkan dengan adanya sistem informasi pengelolaan data penduduk berbasis website ini dapat memudahkan pegawai dalam menyelesaikan pekerjaannya dan dapat membantu penduduk agar mendapatkan pelayanan yang lebih cepat dan tanpa memerlukan banyak waktu. Karena cakupan sistem yang masih terbatas pada wilayah Kelurahan Karang Baru Kota Mataram maka dalam perancangan sistem ini metode yang dianggap cocok dalam perancangan sistemnya adalah metode waterfall dengan tahapan dimulai dari analisis kebutuhan, desain sistem, coding dan testing, penerapan program, serta pemeliharaan.
\end{abstract}

Keywords: Sistem Informasi, Pengelolaan Data Penduduk, Metode Waterfall, Website, PHP, MYSQL.

\section{Pendahuluan}

\subsection{Latar Belakang}

Perkembangan teknologi informasi dengan penggunaan komputer dapat menghasilkan pengolahan data yang cepat, tepat, dan akurat sehingga lebih efektif dan efisien. Sistem Informasi merupakan salah satu bentuk penerapan dari pesatnya laju perkembangan teknologi informasi. Pengelolaan data kependudukan merupakan tanggung jawab pemerintah kabupaten/kota, dimana pelaksanaannya diawali dari kelurahan selaku instansi paling awal untuk melakukan pendaftaran penduduk. Kantor Lurah Karang Baru di Kota Mataram, Provinsi NTB ini memiliki tugas pokok untuk menyelenggarakan urusan pemerintahan, pembangunan, dan kemasyarakatan serta urusan yang dilimpahkan oleh Walikota Kota Mataram sesuai dengan kebutuhan Kelurahan dengan memperhatikan prinsip efisiensi dan peningkatan akuntabilitas. Kantor Lurah Karang Baru Kota Mataram saat ini belum memiliki sistem atau basis data informasi untuk melakukan pengelolaan data kependudukan sehingga masih dilakukan secara manual dimana hal ini akan memperlambat kinerja dari staf-staf Kantor Lurah Karang Baru Kota Mataram. Pengolahan data dan pengelolaannya sebagian sudah menggunakan teknologi komputer namun belum optimal karena masih terbatas pada pengolahan kata dan angka dengan menggunakan Microsoft Word dan Microsoft Excel.

Hal ini tentu menimbulkan berbagai kendala, adapun kendala yang dihadapi adalah sulitnya dalam melakukan pencarian data bila suatu saat data tersebut diperlukan dan kesulitan dalam penyimpanan data karena masih ada data yang menggunakan sistem penyimpanan dalam bentuk berkas fisik, terjadinya ketidak-cocokan dan redundansi data, tidak efisiennya waktu yang digunakan untuk memproses pelayanan kependudukan dan proses pembuatan surat keterangan, surat kelahiran, surat kematian, dan sebagainya.

Sehingga penulis menyimpulkan perlunya perancangan suatu sistem informasi yang dapat mengelola data penduduk secara benar dan cepat sehingga proses pengolahan dan pengelolaan data kependudukan menjadi lebih efektif dan efisien. Oleh karena itu, penulis menawarkan solusi untuk mengatasi beberapa permasalahan tersebut yaitu dengan pembuatan "Sistem Informasi Pengelolaan Data Penduduk Kantor Kelurahan Karang Baru Kota Mataram Berbasis Website" yang dilengkapi dengan database sebagai media penyimpanan datanya. Dengan adanya sistem informasi administrasi kependudukan ini, diharapkan proses pelayanan kepada penduduk akan meningkat dari segi waktu maupun kualitas pelayanannya baik itu pendaftaran penduduk maupun pembuatan surat keterangan 
lainnya yang perlu dilakukan dengan benar dan cepat agar penduduk dapat merasa mendapatkan pelayanan yang memuaskan.

\subsection{Tujuan dan Manfaat}

a. Tujuan.

tujuan dari dibuatnya sistem informasi pengelolaan data penduduk ini adalah sebagai berikut:

1. Merancang sistem informasi pengelolaan data penduduk Kantor Kelurahan Karang Baru Kota Mataram berbasis website dengan PHP MYSQL dan Framework CodeIgniter.

2. Merancang suatu basis data yang dapat menyimpan data-data kependudukan Kantor Lurah Karang Baru Kota Mataram.

3. Menghasilkan informasi dan data yang akurat sehingga dapat membantu menciptakan lingkungan kerja yang produktif di Kantor Lurah Karang Baru Kota Mataram.

4. Meningkatkan pelayanan publik bagi penduduk Kelurahan Karang Baru Kota Mataram.

b. Manfaat.

Manfaat dari pembuatan sistem informasi pengelolaan data penduduk ini adalah sebagai berikut:

1. Bagi Masyarakat atau pihak Instansi terkait

a. Menjadikan pengelolaan data kependudukan di Kantor Lurah Karang Baru Kota Mataram lebih efektif dan efisien.

b. Meningkatkan kinerja staf-staf Kantor Lurah Karang Baru Kota Mataram demi memberikan pelayanan terbaiknya kepada masyarakat.

c. Mempercepat dalam pendataan data penduduk, kelahiran penduduk dan kematian penduduk.

2. Bagi Mahasiswa

a. Memberikan pengalaman pengabdian kepada masyarakat atau pada instansi.

b. Mengimplementasikan ilmu pengetahuan dan pembelajaran yang diperoleh pada saat perkuliahan.

c. Menambah dan meningkatkan pemahaman mahasiswa dalam pembuatan website.

\section{Tinjauan Pustaka}

\subsection{Referensi Terkait}

Sebagai bahan referensi untuk membantu dalam pembuatan sistem informasi kependudukan ini, maka terdapat beberapa jurnal yang terkait dengan pembuatan sistem informasi ini, diantaranya:

1. Pengembangan Sistem Informasi Data Administrasi Penduduk E-SIDAPI di Kecamatan Purbaratu Kota Tasikmalaya, oleh Tuti Alawiyah, Agung Baitul Hikmah dan Bambang Kelana Simpony, pada tahun 2019, tentang pengembangan sistem informasi administrasi kependudukan yang dapat mengelola penduduk yang lahir, pindah datang, meninggal dan pindah keluar menggunakan aplikasi berbasis website pada tingkat kecamatan. Hasil penelitian ini dapat memberi solusi untuk mengelola data kependudukan dengan lebih baik dengan meminimalisasi redudansi data penduduk sehingga dapat menghasilkan laporan data kependudukan yang akurat [1].

2. Sistem Informasi Kepadatan Penduduk Kelurahan atau Desa Studi Kasus pada Kecamatan Bati-Bati Kabupaten Tanah Laut, oleh Winda Aprianti dan Umi Maliha pada tahun 2016, tentang pembuatan suatu Sistem informasi yang penggunaanya dikhususkan untuk BPMPD Kabupaten Tanah Laut memberikan solusi mempermudah pihak instansi untuk pencarian data dan informasi mengenai kepadatan penduduk di setiap desa atau kelurahan, untuk membantu dalam pelaksanaan tugas pokok BPMPD [2].

\subsection{Sistem Informasi}

Sistem informasi adalah kumpulan komponen yang saling berhubungan dalam mengumpulkan, memproses, menyimpan, menyediakan dan mendistribusikan informasi untuk mendukung pengambilan keputusan dan pengendalian di dalam organisasi [3]. Pengertian lain mengatakan bahwa sebuah Sistem Informasi merupakan sekumpulan dari perangkat keras dan perangkat lunak komputer serta perangkat manusia yang akan mengolah data menggunakan perangkat keras dan lunak tersebut. Selain itu data juga memegang peranan penting dalam sistem informasi. Data yang akan dimasukan adalah sebuah sistem infomasi yang dapat berupa formulir-formulir, prosedur-prosedur dan bentuk data lainnya [4]. 


\subsection{Database dan ERD}

Database yaitu sekumpulan data yang saling berintegrasi antara satu sama lain dan terorganisasi berdasarkan sebuah skema atau struktur tertentu dan tersimpan pada sebuah komputer. Database terdiri dari beberapa tabel atau lebih dari satu tabel yang saling terorganisir. Tabel berfungsi untuk menyimpan data dan terdiri dari baris dan kolom. Data yang tersimpan pada tabel tersebut diantaranya dapat ditampilkan, dimodifikasi dan dihapus[5].

ERD (Entity Relationship Diagram) adalah sebuah diagram yang digunakan dalam merancang hubungan antar tabel-tabel dalam basis data. ERD (Entity Relation diagram) berfungsi untuk menggambarkan gambaran dari dunia nyata yang akan diterapkan pada suatu database di sebuah sistem [5].

\subsection{Aplikasi Web, Web Server, dan PHP}

Website dapat diartikan sebagai kumpulan halaman-halaman yang digunakan untuk mempublikasikan informasi berupa teks, gambar dan program multimedia lainnya berupa animasi (gambar gerak, tulisan gerak), suara dan atau gabungan dari semuanya itu baik yang bersifat statis maupun dinamis yang membentuk suatu rangkaian bangunan yang saling terkait antara satu halaman dengan halaman yang lain yang sering disebut sebagai hyperlink [5]. Terdapat dua jenis website yaitu website statis dan website dinamis. Pada website statis komunikasi berjalan secara satu arah dari server ke client sedangkan website dinamis komunikasi berjalan secara dua arah dimana user bisa memasukan data tertentu ke dalam halaman web untuk kemudian diproses oleh server dan menghasilkan output yang diinginkan oleh user [6].

Web server merupakan software dalam server yang berfungsi untuk menerima permintaan request berupa halaman web melalui HTTP atau HTTPS dari klien yang dikenal dengan web browser dan mengirimkan kembali hasilnya dalam bentuk halaman-halaman web yang umumnya berbentuk dokumen HTML [7].

PHP (Hypertext Preprocessor) disebut sebagai bahasa pemrograman server side karena diproses pada komputer server saja. Dengan menggunakan PHP, pembuatan web dimudahkan dalam membuat konten di dalam sebuah halaman karena lebih efektif. Misalnya, untuk melakukan pengulangan secara lebih efektif, meng-input database, dan sebagainya [5].

\subsection{Framework CodeIgniter}

CodeIgniter merupakan sebuah framework php yang bersifat open source dan menggunakan metode MVC (Model, View, Controller) untuk memudahkan developer atau programmer dalam membangun sebuah aplikasi berbasis web tanpa harus membuatnya dari awal. Sedangkan framework adalah kumpulan intruksi-intruksi yang dikumpulkan dalam class dan function-function dengan fungsi masing-masing untuk memudahkan developer dalam memanggilnya tanpa harus menuliskan syntax program yang sama berulang-ulang serta dapat menghemat waktu. Codeigniter menggunakan konsep M-V-C (Model-View-Controller) yang memungkinkan pemisahan antara layer application-logic dan presentation. Dengan konsep ini kode PHP, query Mysql, Javascript dan CSS dapat saling dipisah-pisahkan sehingga ukuran file menjadi lebih kecil dan lebih mudah dalam perbaikan kedepannya atau maintenance [8].

\subsection{XAMPP}

XAMPP adalah perangkat lunak bebas, yang mendukung banyak sistem operasi, merupakan kompilasi dari beberapa program. Fungsinya adalah sebagai server yang berdiri sendiri (localhost), yang terdiri atas program Apache HTTP Server, MySQL database, dan penerjemah bahasa yang ditulis dengan bahasa pemrograman PHP dan Perl. Nama XAMPP merupakan singkatan dari X (empat sistem operasi apapun), Apache, MySQL, PHP dan Perl [9].

\subsection{MySQL}

MySQL adalah sebuah program Database server yang mampu menerima dan mengirimkan data dengan cepat dengan menggunakan perintah - perintah SQL (Structured Query Language). MySQL merupakan database yang pertama kali didukung oleh bahasa pemrograman script untuk internet (PHP dan Perl). MySQL lebih sering digunakan untuk membangun aplikasi berbasis web, umumnya pengembangan aplikasinya menggunakan bahasa pemrograman script PHP [10]. 


\section{Metode Pengabdian masyarakat}

\subsection{Identifikasi Masalah}

Metode pelaksanaan dari kegiatan pengabdian ini diawali dengan melakukan pengidentifikasian masalah dengan turun langsung ke masyarakat atau instansi tempat akan melaksanakan kegiatan yaitu Kelurahan Kantor Karang Baru Kota Mataram. Berdasarkan pengidentifikasian masalah, didapatkan bahwa Kantor Lurah Karang Baru saat ini belum memiliki sistem atau basis data informasi untuk melakukan pengelolaan data kependudukan sehingga hal ini menimbulkan kendala seperti redundansi data dan kurang maksimalnya pelayanan dalam pembuatan surat-surat keterangan untuk masyarakat.

\subsection{Pengumpulan Data}

Setelah permasalahan telah berhasil diidentifikasi selanjutnya dilakukan pengumpulan data untuk mendukung perancangan sistem. Pengumpulan data dilakukan melalui studi literatur dan studi lapangan. Studi literatur dilakukan dengan mengumpulkan informasi yang dibutuhkan dari buku dan jurnal-jurnal penelitian yang telah dilakukan sebelumnya. Studi lapangan dilakukan dengan melakukan peninjauan langsung di Kantor Kelurahan Karang Baru Kota Mataram untuk mengetahui permasalahan yang terdapat di lapangan. Pengumpulan data dengan wawancara dan diskusi dengan staf pada Seksi Sosial dan Pemberdayaan Masyarakat Kantor Lurah Karang Baru Kota Mataram juga diperlukan untuk memperoleh data-data yang belum ditemukan pada saat melakukan pengamatan langsung di lapangan mengingat komunikasi penting untuk menghasilkan sistem yang baik sesuai dengan kebutuhan dan harapan pengguna.

\subsection{Metode Perancangan Sistem}

Pengembangan perangkat lunak Sistem Informasi Pengelolaan Data Penduduk Kantor Kelurahan Karang Baru Kota Mataram Berbasis Website ini menggunakan SDLC (System Development Life Cycle) memiliki beberapa model dalam dengan model waterfall (linear sequential model). Alasan penggunaan model waterfall dalam pembuatan sistem informasi ini dikarenakan sistem yang dibuat tidak terlalu besar dan lingkup pengembangannya tidak begitu luas sehingga akan lebih memudahkan jika menggunakan model waterfall yang pendekatannya dilakukan secara sistematis dan berurutan.

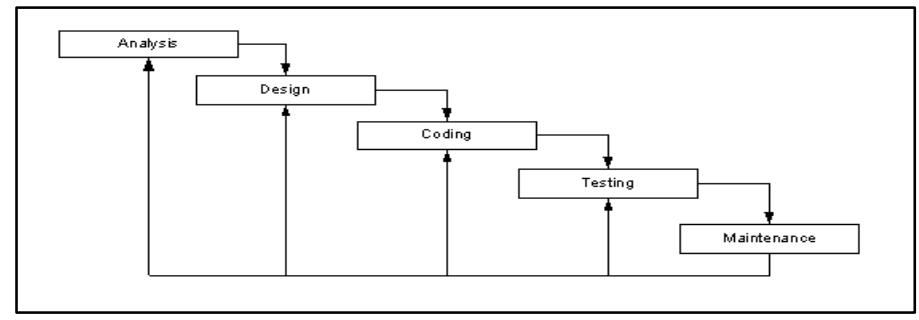

Gambar 1. Metode Penelitian Waterfall

\subsection{Desain Sistem}

Tahap perancangan Sistem Informasi Pengelolaan Data Penduduk Kantor Kelurahan Karang Baru Kota Mataram Berbasis Website ini menggunakan tiga diagram UML yang terdiri dari use case diagram, activity diagram, serta ERD.

\subsubsection{Use Case Diagram}

Berikut ini merupakan Use Case Digaram dari sistem informasi pengelolaan data penduduk Kantor Kelurahan Karang Baru Kota Mataram yang ditunjukan pada gambar 2. 


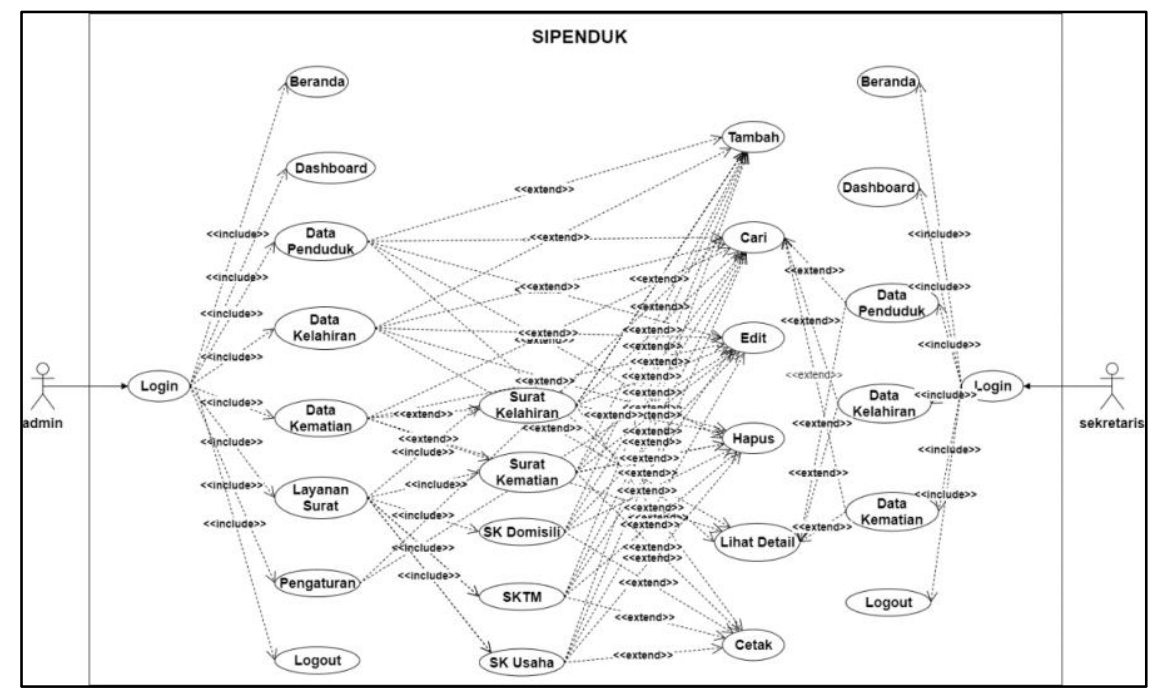

Gambar 2. Use case diagram

Gambar 2 merupakan diagram use case pada sistem informasi pengelolaan data penduduk Kantor Kelurahan Karang Baru Kota Mataram. Diagram di atas menunjukkan bahwa ada 2 level pengguna yang dapat menggunakan sistem ini, yaitu staf administrasi dan sekretaris kelurahan. Use case diagram yang disajikan pada Gambar 2 mendeskripsiskan interaksi aktor, yaitu admin dan sekretaris dalam pengelolaan data.

\subsubsection{Activity Diagram}

Berikut merupakan activity diagram dari sistem informasi pengelolaan data penduduk Kantor Kelurahan Karang Baru Kota Mataram.

1. Proses login

Gambar 3 mengilustrasikan aktivitas untuk masuk ke dalam sistem melalui proses login. Ketika pertama kali diakses, sistem akan menampilkan form login yang harus diisi oleh admin, dan selanjutnya admin akan meng-input-kan username dan password sesuai dengan data yang telah terdaftar pada basis data.

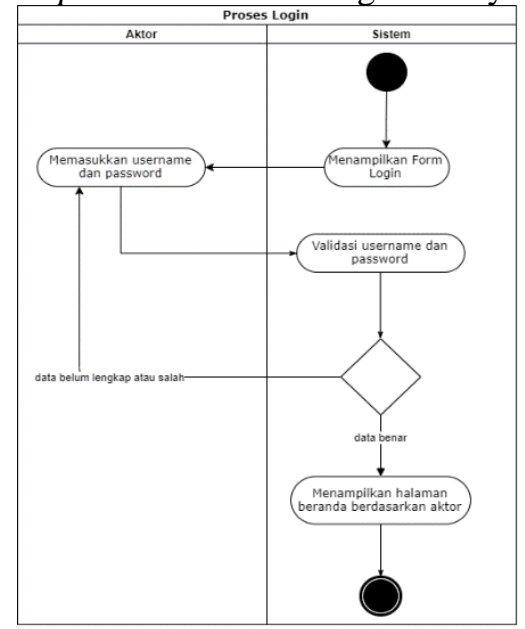

Gambar 3. Proses login

2. Proses menambahkan data penduduk

Gambar 4 mengilustrasikan aktivitas yang terjadi ketika admin menambahkan data penduduk. Ketika admin memilih fitur tambah data penduduk maka sistem akan menampilkan form tambah data penduduk yang harus diisi oleh admin. 


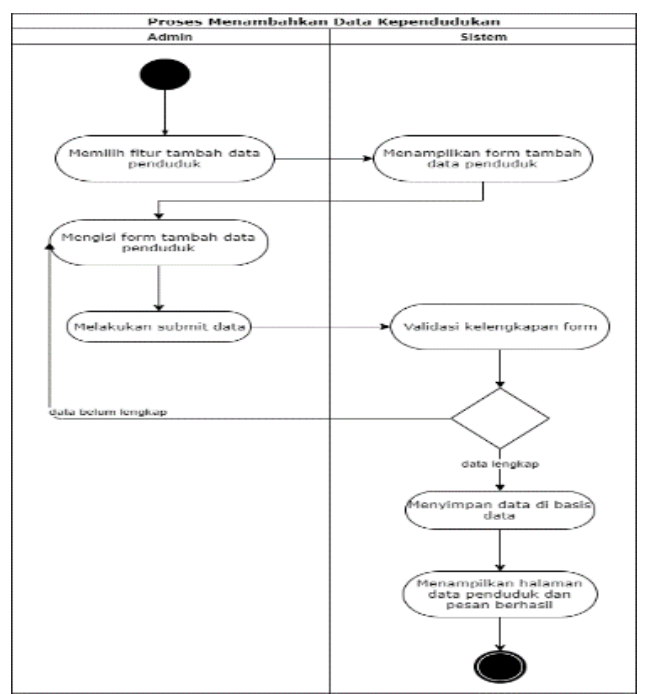

3. Proses memperbarui data penduduk

Gambar 4. Proses menambahkan data penduduk

Gambar 5 mengilustrasikan aktivitas yang terjadi ketika admin melakukan pembaruan data penduduk. Admin harus memilih data penduduk yang akan diperbarui dan sistem akan menampilkan form untuk melakukan pembaruan data penduduk. Kemudian admin dapat memilih field atau atribut apa yang datanya akan diperbarui dan melakukan simpan data.

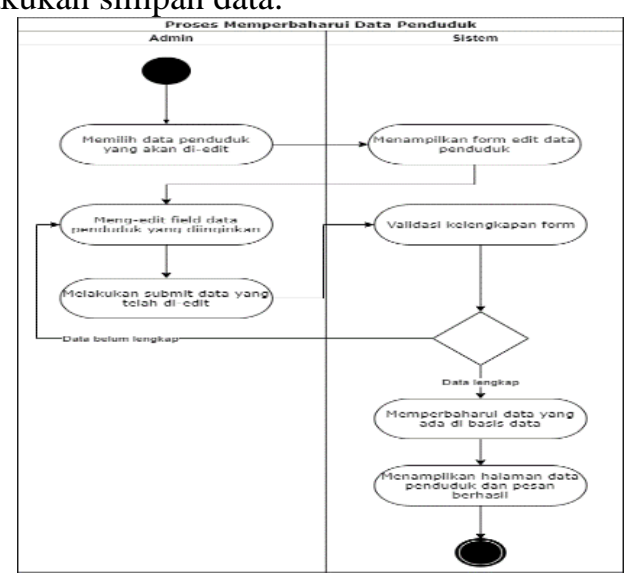

Gambar 5. Proses memperbarui data penduduk

Selain merubah data penduduk, admin juga dapat menghapus data penduduk jika diperlukan dengan Langkah sebelumnya mirip seperti jika akan memperbaharui data seperti penjelasan sebelumnya.

4. Proses melihat data layanan surat

Gambar 6 mengilustrasikan aktivitas yang terjadi ketika admin memilih fitur untuk melihat data layanan surat. Ketika admin mengakses halaman data layanan surat maka sistem akan menampilkan daftar data layanan surat yang tersimpan di sistem, jika belum terdapat data, maka sistem akan menampilkan keterangan belum ada data.

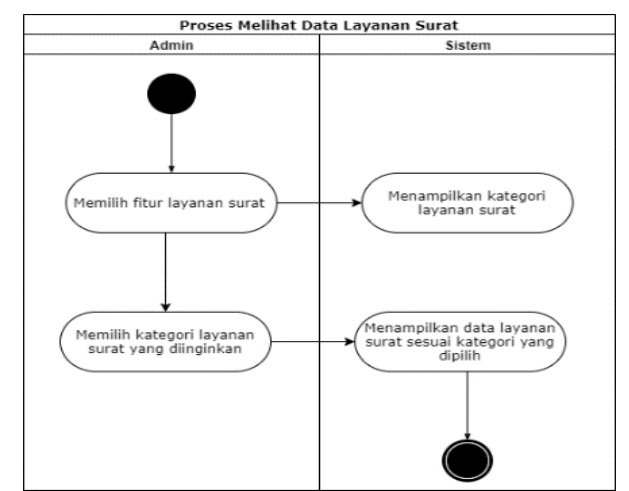

Gambar 6. Proses melihat data layanan surat 
5. Proses mencetak data layanan surat

Gambar 7 mengilustrasikan aktivitas yang terjadi ketika admin memilih fitur untuk mencetak data surat. Untuk mengakses halaman ini admin harus terlebih dahulu membuka halaman data surat. Selanjutnya admin harus memilih data surat yang akan dicetak dan sistem akan mengarahkan admin ke halaman baru untuk mencetak surat dimana admin dapat mengatur properties untuk pencetakan surat sesuai dengan kebutuhan

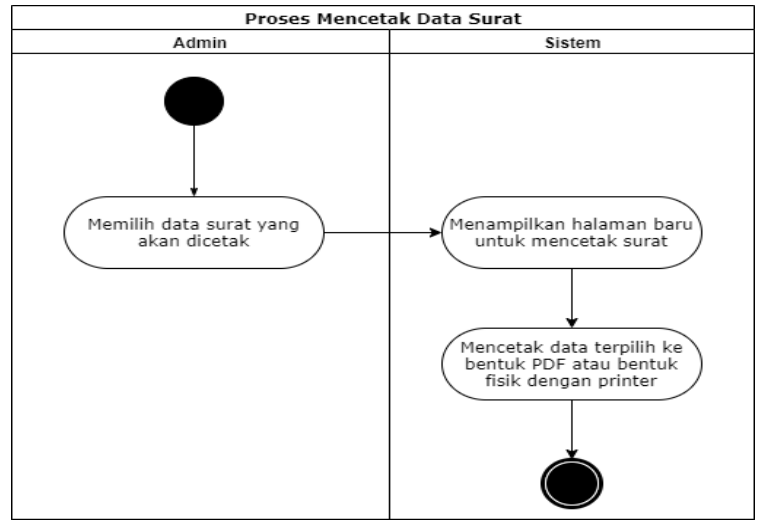

Gambar 7. Proses mencetak data layanan surat

\subsubsection{Entity Relationship Diagram (ERD)}

Gambar 8 menunjukkan rancangan basis data dari sistem informasi pengelolaan data penduduk Kantor Kelurahan Karang Baru Kota Mataram.

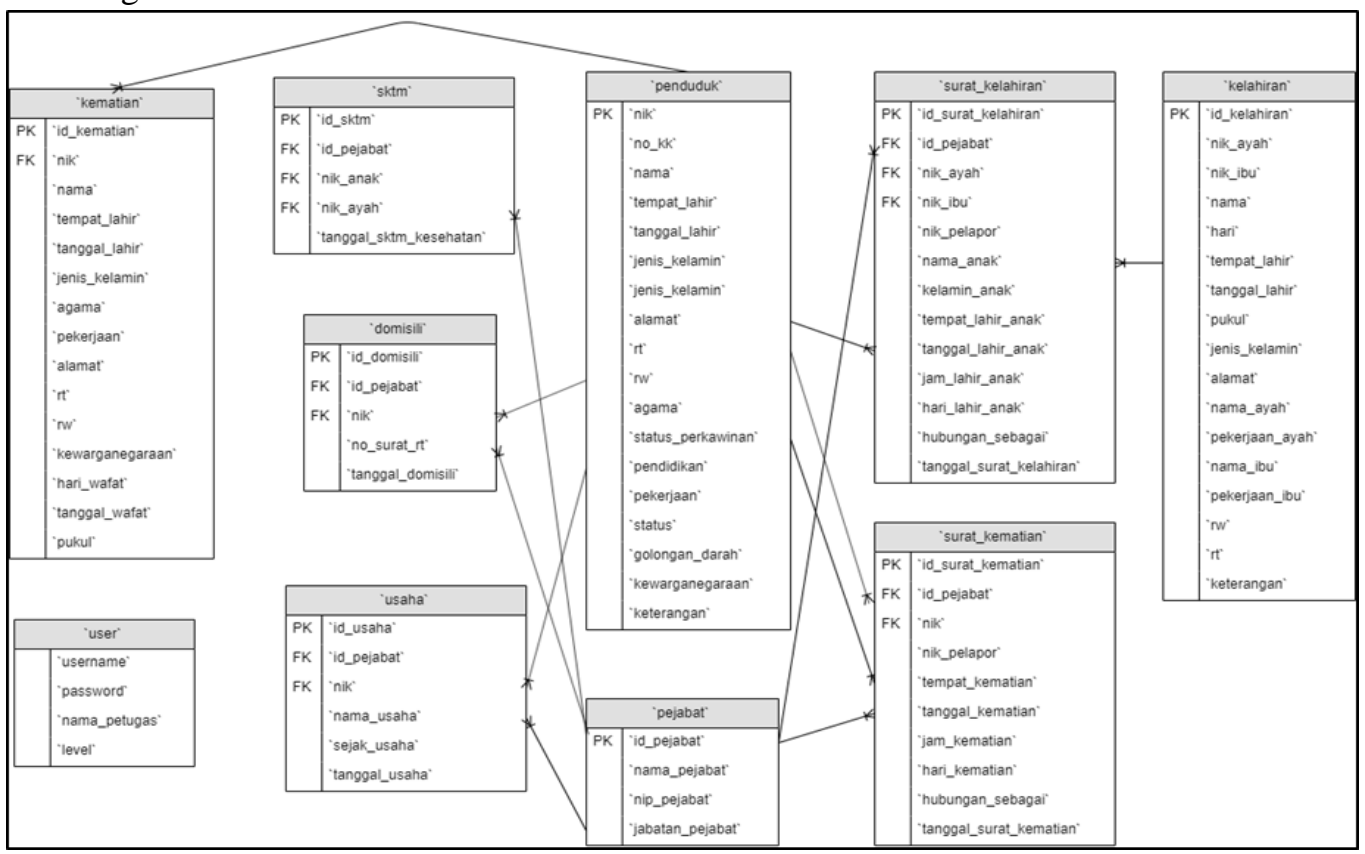

Gambar 8. ERD sistem informasi pengelolaan data penduduk Kantor Kelurahan Karang Baru Kota Mataram

\subsection{Implementasi Sistem}

Pengimplementasian Sistem Informasi Pengelolaan Data Kependudukan Kelurahan Karang Baru ini menggunakan PHP sebagai bahasa pemrograman untuk sisi server-nya dan framework CodeIgniter dengan konsep M-V-C (Model-View-Controller) dalam pengembangannya. Digunakan pula XAMPP dan MySQL sebagai localhost dan database server. 


\subsubsection{Implementasi Interface Sistem}

Berikut adalah implementasi tampilan (interface) program dari sistem informasi pengelolaan data penduduk Kantor Kelurahan Karang Baru Kota Mataram.

1. Tampilan halaman Login

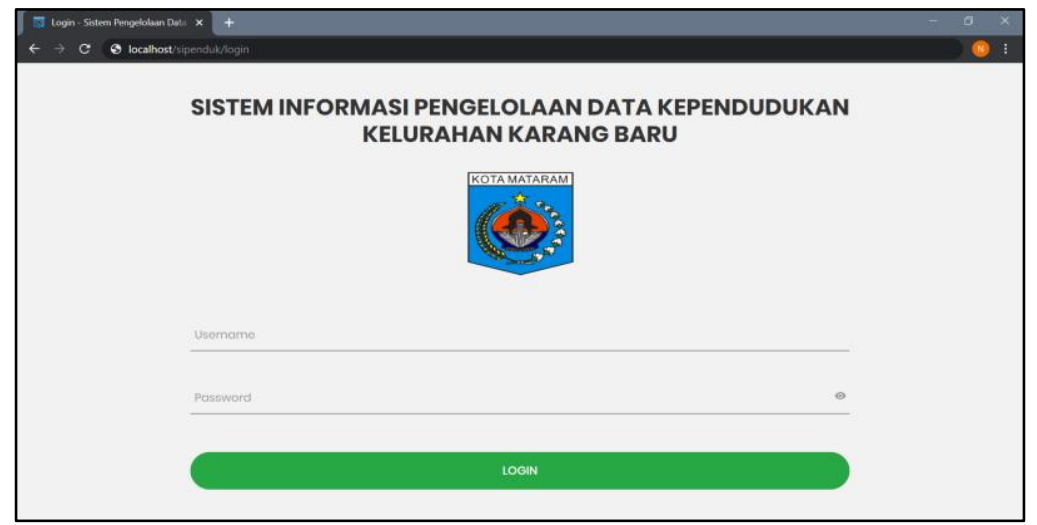

Gambar 9. Halaman login

Pada Gambar 9 merupakan implementasi halaman login dari dari sistem informasi pengelolaan data penduduk Kantor Kelurahan Karang Baru Kota Mataram. Halaman ini merupakan tampilan yang akan pertama kali muncul ketika pengguna mengakses program. Untuk masuk ke dalam sistem pengguna perlu untuk memasukkan username dan password yang sesuai dengan data di database.

2. Tampilan halaman data penduduk

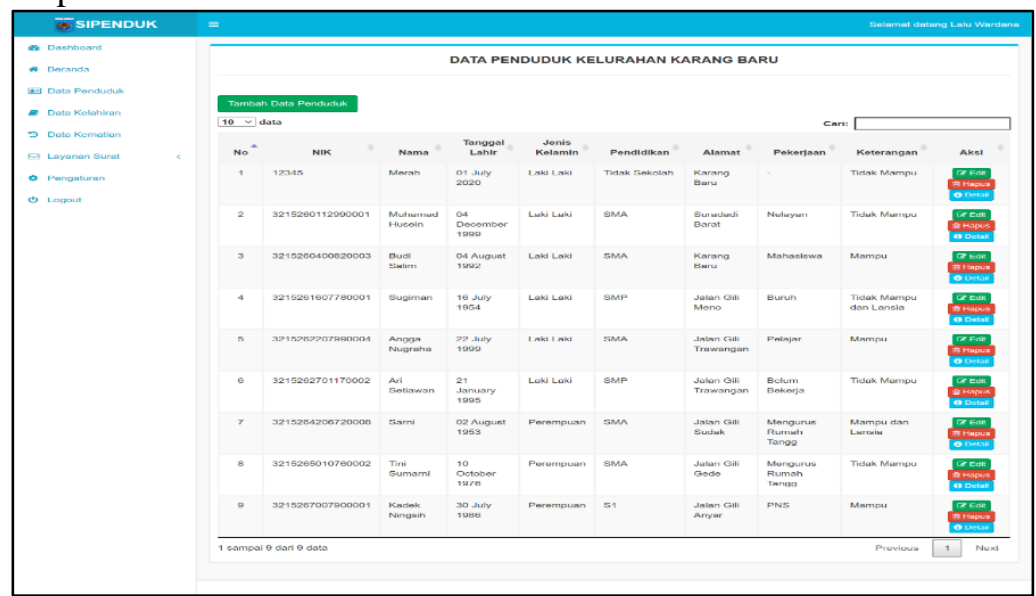

Gambar 10. Tampilan halaman data penduduk

Pada Gambar 10 merupakan implementasi dari halaman data penduduk. Halaman ini berfungsi untuk menampilkan daftar data penduduk Kelurahan Karang Baru Kota Mataram. Pada halaman ini terdapat fitur tambah data penduduk yang akan mengarahkan admin ke halaman tambah data penduduk dan juga terdapat fitur cari data penduduk untuk memudahkan admin dalam menemukan data penduduk tertentu. Pada bagian aksi terdapat beberapa fungsi yaitu tombol untuk mengarahkan admin ke halaman edit data penduduk, tombol untuk melakukan hapus data penduduk dan tombol untuk mengarahkan admin ke halaman lihat rincian data penduduk.

3. Tampilan halaman tambah data penduduk 


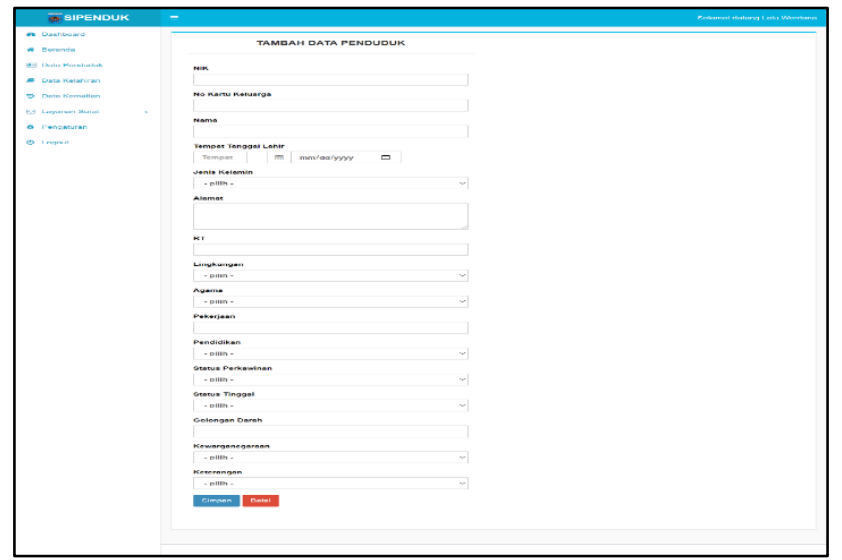

Gambar 11. Halaman tambah data penduduk

Gambar 11 merupakan tampilan form untuk admin melakukan tambah data penduduk, agar data dapat tersimpan di database, form harus diisi dengan lengkap sesuai dengan data yang diminta. Setelah admin mengklik tombol simpan maka sistem akan kembali ke halaman daftar data penduduk dan admin dapat melihat bahwa penambahan data yang dilakukan sudah berhasil.

4. Tampilan halaman edit data penduduk

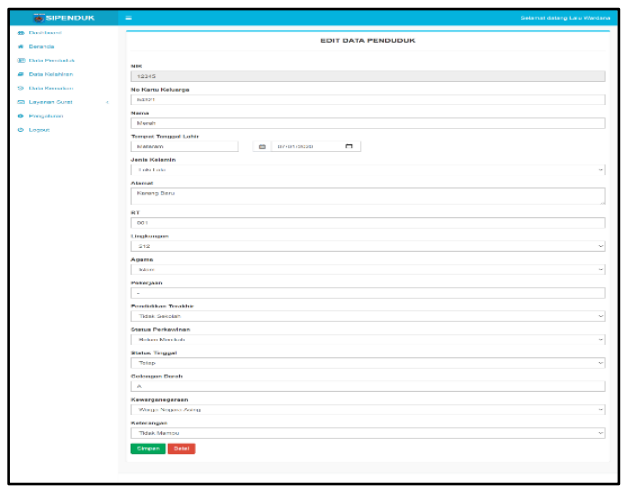

Gambar 12. Halaman edit data penduduk

Pada Gambar 12 merupakan tampilan form untuk admin melakukan edit data penduduk, dengan form ini admin dapat memperbarui data penduduk yang ada. Pada bagian bawah pojok kiri terdapat tombol untuk menyimpan perubahan data penduduk dan tombol untuk melakukan pembatalan edit data penduduk jika tidak jadi melakukan pembaruan data. Setelah admin meng-klik tombol simpan maka sistem akan kembali ke halaman daftar data penduduk dan admin dapat melihat bahwa pembaruan data sudah berhasil tersimpan.

5. Tampilan halaman hapus data penduduk

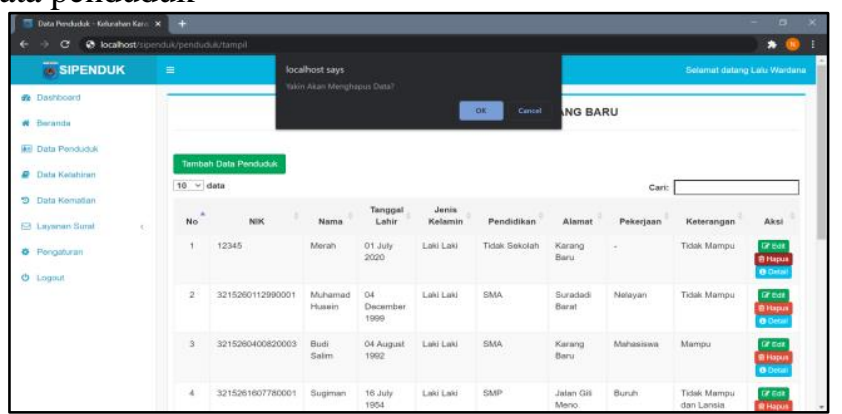

Gambar 13. Tampilan halaman hapus data penduduk

Pada Gambar 13 merupakan tampilan halaman ketika admin akan melakukan hapus data penduduk sehingga data penduduk yang dipilih akan otomatis terhapus dari daftar penduduk.

6. Tampilan halaman detail informasi data penduduk 


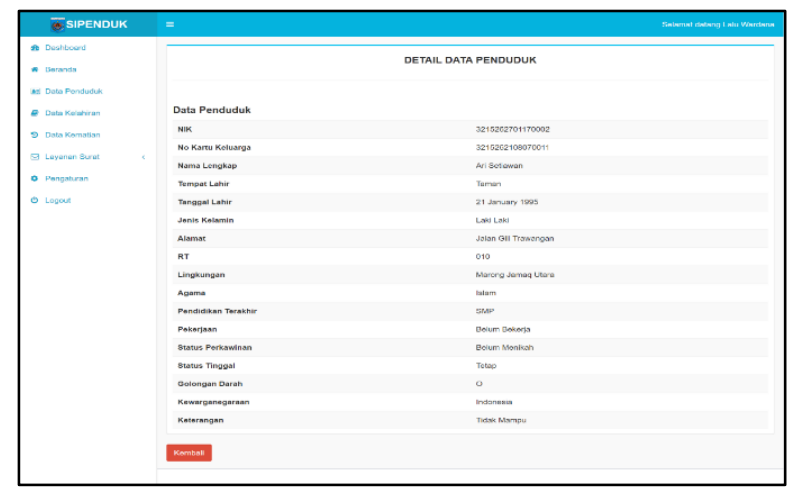

Gambar 14. Halaman detail informasi data penduduk

Gambar 14 merupakan tampilan halaman ketika admin memilih fitur untuk melihat detail data penduduk. Ketika admin meng-klik tombol detail pada salah satu data penduduk maka akan diarahkan ke halaman ini yang akan menampilkan rincian informasi dari data penduduk yang dipilih.

7. Tampilan halaman data layanan surat kelahiran

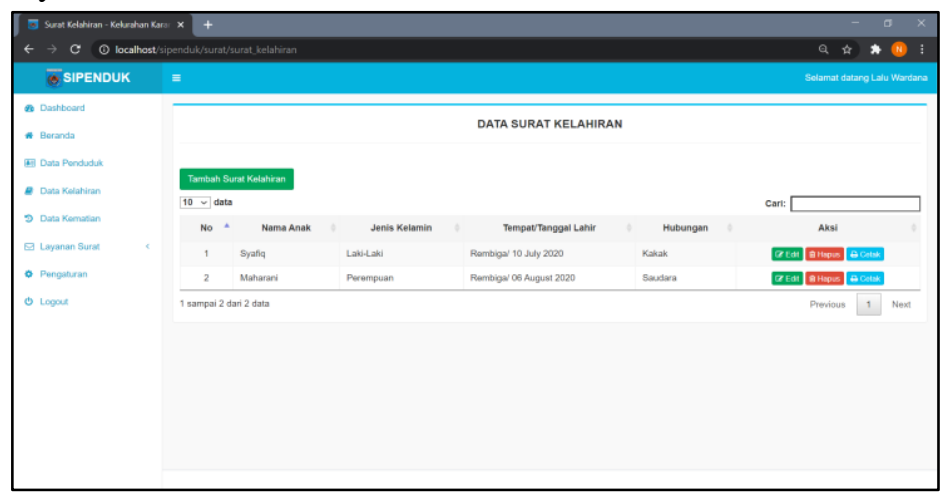

Gambar 15. Tampilan halaman data layanan surat kelahiran

Pada Gambar 15 merupakan implementasi dari halaman data surat kelahiran. Halaman ini berfungsi untuk menampilkan daftar surat kelahiran pada Kelurahan Karang Baru Kota Mataram.

8. Tampilan halaman cetak data surat kelahiran

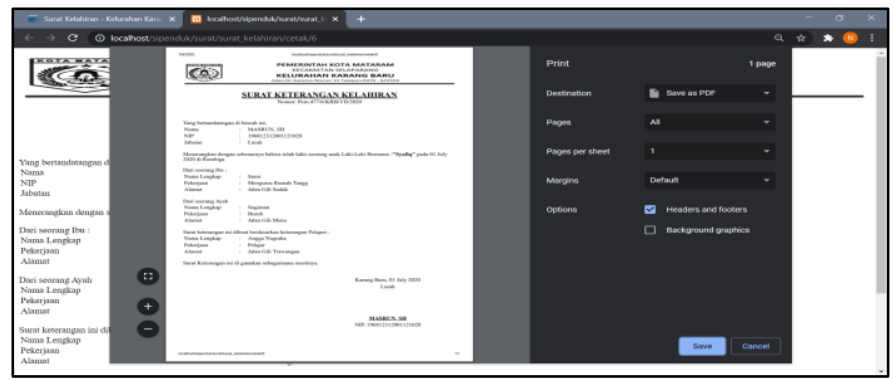

Gambar 16. Tampilan halaman cetak data surat kelahiran

Gambar 16 merupakan tampilan halaman ketika admin memilih fitur untuk melakukan cetak data surat kelahiran. Ketika admin meng-klik tombol cetak pada salah satu data surat kelahiran maka akan diarahkan ke halaman baru yang akan menampilkan rincian pengaturan untuk mencetak surat kelahiran.

\section{HaSil Dan PeMbahasan}

Penulis melakukan pengujian bagi aplikasi yang telah dibuat dengan memberikan kuesioner kepada 10 orang responden yang merupakan pegawai Kantor Kelurahan Karang Baru Kota Mataram. Hal ini dilakukan untuk mengetahui apakah sistem sudah sesuai dengan kebutuhan sekaligus untuk bahan evaluasi sistem. Pilihan jawaban dari kuesioner terdiri dari 5 kategori yaitu Sangat Setuju (SS), Setuju (S), Biasa Saja (BS), Tidak Setuju (TS) dan Sangat Tidak Setuju (STS). Parameter pengujian yang digunakan pada metode ini adalah sebagai berikut:

a. Tampilan sistem sudah sangat baik dan mudah di gunakan.

b. Sistem mempermudah pekerjaan petugas perpustakaan. 
c. Sistem peminjaman dan pengembalian buku sudah akurat.

d. Sistem sudah menghasilkan laporan data buku dan data peminjaman buku yang akurat.

e. Sistem sangat menunjng kinerja instansi.

Berikut merupakan hasil dari pengujian yang dilakukan terhadap 10 responden yang merupakan pegawai Kantor Kelurahan Karang Baru Kota Mataram.

Tabel 1. Persentase hasil pengujian sistem

\begin{tabular}{|c|c|c|c|c|c|c|}
\hline \multirow[t]{2}{*}{ No } & \multirow[t]{2}{*}{ Pernyataan } & \multicolumn{5}{|c|}{ Jawaban } \\
\hline & & SS & $\mathbf{S}$ & BS & TS & STS \\
\hline 1 & Tampilan sistem sudah sangat baik dan mudah digunakan. & 4 & 6 & 0 & 0 & 0 \\
\hline 2 & Sistem mempermudah pekerjaan pegawai. & 8 & 2 & 0 & 0 & 0 \\
\hline 3 & Sistem sudah bekerja sesuai kegunaan dan fungsinya. & 5 & 5 & 0 & 0 & 0 \\
\hline 4 & $\begin{array}{l}\text { Sistem sudah dapat menghasilkan keluaran berupa informasi kependudukan } \\
\text { dan surat. }\end{array}$ & 5 & 5 & 0 & 0 & 0 \\
\hline 5 & Sistem sudah sesuai dengan kebutuhan instansi. & 7 & 3 & 0 & 0 & 0 \\
\hline & Total & 29 & 21 & $\mathbf{0}$ & $\mathbf{0}$ & $\mathbf{0}$ \\
\hline & Persentase & $58 \%$ & $42 \%$ & & & \\
\hline
\end{tabular}

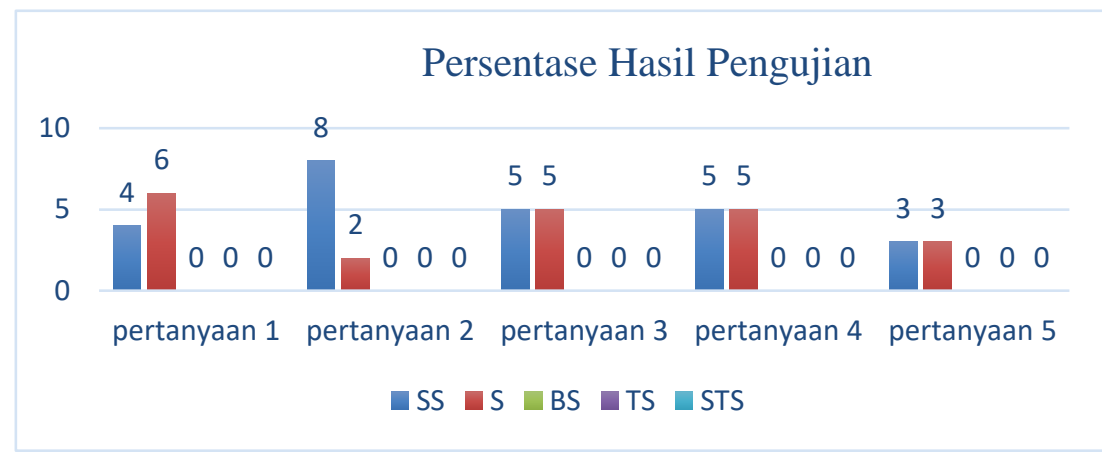

Gambar 17. Grafik persentase hasil pengujian

Berdasarkan hasil pengujian kuesioner terhadap 10 responden mengenai kepuasan penggunaan Sistem Informasi Pengelolaan Data Kependudukan Kelurahan Kota Mataram yang telah dilakukan, maka didapatkan persentase hasil dari pernyataan responden yaitu Sangat Setuju sebesar 58\% atau sebanyak 29 poin dan responden yang memilih Setuju sebesar $42 \%$ atau sebanyak 21 poin. Sehingga dapat disimpulkan bahwa sistem ini berperan dalam memudahkan dan membantu pegawai Kantor Kelurahan Karang Baru Kota Mataram dalam menyelesaikan pekerjaannya.

\section{KESIMPULAN DAN SARAN}

\subsection{Kesimpulan}

Berdasarkan pembuatan Sistem Informasi Pengelolaan Data Kependudukan Kantor Kelurahan Karang Baru Kota Mataram, dapat diambil beberapa kesimpulan sebagai berikut:

1. Perancangan Sistem Informasi Pengelolaan Data Kependudukan Kantor Kelurahan Karang Baru Kota Mataram berbasis website dengan PHP MySQL dan framework CodeIgniter ini telah dapat diselesaikan dengan didasarkan pada hasil analisis terhadap kebutuhan serta lingkungan kerja di Kantor Lurah Karang Baru Kota Mataram.

2. Pembuatan sistem informasi administrasi kependudukan ini dapat membantu dalam pengolahan data kependudukan seperti data penduduk, data kelahiran, data kematian dan data usaha. Dengan adanya sistem informasi ini juga dapat membantu melakukan pengolahan data kependudukan secara efektif dan efisien karena telah menggunakan sistem basis data.

3. Penggunaan sistem informasi ini dapat meminimalisasi terjadinya kesalahan dan kehilangan data karena semua data telah tersimpan di sistem basis data.

4. Pemanfaatan sistem ini dapat memperbaiki kualitas layanan publik di lingkungan Kantor Kelurahan Karang Baru Kota Mataram karena dapat menghasilkan informasi dengan lebih cepat.

5. Berdasarkan hasil kuesioner pengujian sistem dengan responden pegawai Kantor Kelurahan Karang Baru Kota Mataram, 60\% responden setuju bahwa tampilan sistem sudah sangat baik dan mudah digunakan, 80\% 
responden menyatakan sangat setuju bahwa sistem mempermudah pekerjaan pegawai, 50\% responden sangat setuju bahwa sistem sudah bekerja sesuai kegunaan dan fungsinya, $50 \%$ responden menyatakan sangat setuju pada pernyataan sistem sudah dapat menghasilkan keluaran berupa informasi kependudukan dan surat, serta $70 \%$ responden menyatakan sangat setuju bahwa Sistem sudah sesuai dengan kebutuhan instansi. Sehingga dapat disimpulkan bahwa sistem yang dibuat mempunyai kemampuan yang baik jika diterapkan, karena membantu pegawai dalam melakukan pekerjaannya dengan adanya pengolahan data yang menjadi lebih otomatis.

\subsection{Saran}

Adapun saran yang dapat diberikan penulis agar Sistem Informasi Pengelolaan Data Kependudukan Kantor Kelurahan Karang Baru Kota Mataram ini menjadi lebih baik di masa yang akan datang yakni sebgai berikut:

1. Sistem informasi ini diharapkan kedepannya dapat memasukan data kependudukan secara banyak dengan cara meng-import langsung data kependudukan dari excel.

2. Untuk pengembangan selanjutnya diharapkan cakupan sistem menjadi lebih kompleks dan dilengkapi dengan data demografi penduduk, peta potensi SDM dan potensi sarana dan prasarana.

\section{DAfTAR Pustaka}

[1] T. Alawiyah, A. B. Hikmah dan B. K. Simpony, "Sistem Informasi Data Administrasi Penduduk E-SIDAPI," IJCIT (Indonesian Journal on Computer and Information Technology), 4 (2), pp. 189-195, 2019.

[2] W. Aprianti dan U. Maliha, "Sistem Informasi Kepadatan Penduduk Kelurahan atau Desa Studi Kasus pada Kecamatan Bati-Bati Kabupaten Tanah Laut," Jurnal Sains dan Informatika, vol.2, no.1, ISSN: 2460-173X, pp. 21-28, 2016.

[3] A. Kadir, Pengenalan Sistem Informasi. Yogyakarta: CV. Andi Offset, 2014.

[4] A. Kristanto, Perancangan SI dan Aplikasinya. Yogyakarta: Penerbit Gava Media, 2003.

[5] M. R. Arief, Pemrograman Web Dinamis Menggunakan PHP \& MySQL. Yogyakarta: Andi, 2011.

[6] F. Marisa, Web Programming untuk Membangun Portal. Yogyakarta: CV Budi Utama, 2017.

[7] F. T. Yuniko dan F. K. Putra, "Penerapan Teknologi Informasi Web Programming untuk Meningkatkan Pelayanan Publik Dalam Bidang Kebijakan Administrasi Kekematianan," JOISIE (Journal of Information Systems and Informatics Engineering), 1(1), 13, 2019.

[8] B. Sidik, Pemrograman Web dengan PHP. Bandung: Informatika, 2012.

[9] B. Raharjo, I. Heryanto, dan E. Rosdiana K. Modul Pemograman Web HTML, PHP \& MySQL. Bandung: Modula, 2010.

[10] A. Simangunsong, "Sistem Informasi Pengarsipan Dokumen Berbasis Web," Jurnal Mantik Penusa, vol.2, no.1, E-ISSN 2580-9741, pp. 11-19, 2018. 